\title{
fififorifder Beitldhrift.
}

Sheraubagegcben von

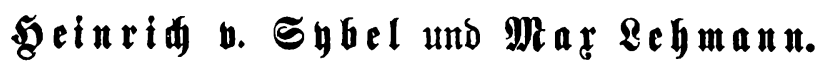

Der ganzen Reihe 65. Band.

Neue Folge 29. Banto.

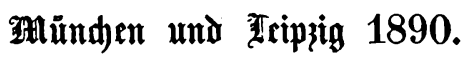

Drudf und Berlag von $\Re$. Oldenbourg.

Reprinted with the permission of $R$. Oldenbourg Verlag JOHNSON REPRINT CORPORATION JOHNSON REPRINT COMPANY LTD. 111 Fifth Avenue, New York, N.Y. 10003 Berkeley Square House, London, W. 1 
First reprinting, I 968, Johnson Reprint Corporation Printed in the United States of America 